\title{
Adenoid cystic carcinoma of the breast - an aggressive presentation with pulmonary, kidney, and brain metastases: a case report
}

\author{
Hasnae Alaoui Mhamdi ${ }^{*}$, Hampig Raphael Kourie ${ }^{2}$, Christiane Jungels ${ }^{3}$, Philippe Aftimos ${ }^{3}$, Rhizlane Belbaraka ${ }^{1}$ \\ and Martine Piccart-Gebhart ${ }^{3}$
}

\begin{abstract}
Background: Adenoid cystic carcinoma of the breast is a rare malignant neoplasm associated with an excellent prognosis and a very rare occurrence of metastases.

Case presentation: We report the case of an aggressive presentation in a 65-year-old woman, of Belgian origin, who was diagnosed as having adenoid cystic carcinoma of the breast and developed metastases to her lung, kidney, and brain.

Conclusions: We describe similar cases reported in the literature and discuss the molecular characteristics and treatment paradigm of this controversially aggressive disease entity.
\end{abstract}

Keywords: Breast, Metastatic adenoid cystic carcinoma, Triple negative, Treatment

\section{Background}

More than $90 \%$ of breast cancers are ductal and lobular carcinomas; the remaining 10\% represent a heterogenous group of rare histologies of breast cancer that have different clinical, pathological, and prognostic features. The major issue in the management of these rare tumors is the absence of clinical trials enrolling these patients to determine the best treatment. Adenoid cystic carcinoma (ACC) is one of these rare tumors, representing less than $0.1 \%$ of all patients diagnosed with breast cancer. It affects mainly women aged 50 to 60 . It is usually a "triple negative" breast cancer expressing neither hormone receptors nor HER2-neu [1, 2]. Despite being a triple negative breast cancer (TNBC), ACC is usually an indolent malignancy with a very good prognosis, when confined to the breast. Lymph node involvement is very rare not exceeding $2 \%$, and distant metastases are exceptional $[3,4]$.

Here, we report a rare case of ACC of the breast metastasizing to the kidney and the brain. We present a complete review of the literature on similar cases and we

\footnotetext{
* Correspondence: hasnae1686@hotmail.com

'Department of Medical Oncology, University Hospital of Marrakech, Marrakech, Morocco

Full list of author information is available at the end of the article
}

discuss the corresponding molecular characteristics and treatment modalities of this intriguing entity.

\section{Case presentation}

A 65-year-old woman, of Belgian origin, with an unremarkable past medical history and no family history, was diagnosed in 2009 with ACC of her left breast. The tumor measured $8 \mathrm{~cm}$ (T3) and was triple negative. She underwent mastectomy with lymph node dissection, followed by radiation therapy. All lymph nodes were free of disease.

The disease relapsed first locally as a regular, mobile, and dense nodule of $12.7 \times 11.7 \mathrm{~mm}$; it was resected in December 2013. Then the disease relapsed as a pulmonary nodule in 2014, histologically confirmed, treated first with eight cycles of mitoxantrone with good tolerance followed by pulmonary lobectomy in view of the persistence of lesions at the lower lobe of her left lung. A next generation sequencing of 400 genes of the primary tumor did not show any significant gene aberration.

In 2015, a kidney cyst was detected; a fine-needle aspiration of this cyst showed malignant cells. A left nephrectomy confirmed a distant metastasis of the ACC of the breast.

In 2016, neurologic symptoms prompted a brain magnetic resonance imaging (MRI), which revealed metastasis 
Table 1 Literature review of other reported cases of advanced cystic adenoid carcinoma of the breast

\begin{tabular}{|c|c|c|c|c|c|}
\hline Cases & $\begin{array}{l}\text { Patient } \\
\text { (age (years)/gender) }\end{array}$ & $\begin{array}{l}\text { Distant } \\
\text { metastasis }\end{array}$ & Treatment & Survival/prognostic & Time to relapse \\
\hline $\begin{array}{l}\text { Herzberg } \\
\text { et al. [9] }\end{array}$ & 57 , female & Kidney & Mastectomy/nephrectomy & $\begin{array}{l}\text { 5-year disease-free survival, } \\
\text { then lost to follow-up }\end{array}$ & $\begin{array}{l}\text { Distant relapse: } \\
6 \text { years }\end{array}$ \\
\hline $\begin{array}{l}\text { Vranic } \\
\text { et al. [10] }\end{array}$ & 76 , female & Kidney & Mastectomy/radical nephrectomy & No information after relapse & $\begin{array}{l}\text { Distant relapse: } \\
5 \text { years }\end{array}$ \\
\hline $\begin{array}{l}\text { Koller } \\
\text { et al. [11] }\end{array}$ & 49, female & Brain, lungs & $\begin{array}{l}\text { Breast surgery/Chemotherapy/radiation/left } \\
\text { parieto-occipital craniotomy }\end{array}$ & $\begin{array}{l}\text { No relapse at } 20 \text { months } \\
\text { from the surgery }\end{array}$ & $\begin{array}{l}\text { Local relapse: } \\
1 \text { year. Distant } \\
\text { relapse: } 8 \text { years }\end{array}$ \\
\hline $\begin{array}{l}\text { Silva } \\
\text { et al. [12] }\end{array}$ & 37, female & $\begin{array}{l}\text { Brain, liver, } \\
\text { lungs, bone }\end{array}$ & $\begin{array}{l}\text { Radical mastectomy/adjuvant chemotherapy } \\
\text { (six cycles of adriamycin and cyclophosphamide)/ } \\
\text { radiotherapy/palliative chemotherapy } \\
\text { (docetaxel plus vinorelbine and 5FU in second line) }\end{array}$ & $\begin{array}{l}\text { The patient died } 1 \text { year after } \\
\text { developing brain metastasis }\end{array}$ & $\begin{array}{l}\text { Distant relapse: } \\
2 \text { years }\end{array}$ \\
\hline Our case & 65 , female & $\begin{array}{l}\text { Brain, lung, } \\
\text { kidney }\end{array}$ & $\begin{array}{l}\text { Mastectomy/palliative chemotherapy (mitoxantrone)/ } \\
\text { thoracotomy/radical nephrectomy/craniotomy } \\
\text { plus radiotherapy }\end{array}$ & $\begin{array}{l}\text { Patient still alive, now } \\
\text { presenting liver lesions }\end{array}$ & $\begin{array}{l}\text { Local relapse: } \\
4 \text { years. Distant } \\
\text { relapses: } 5 \text { years }\end{array}$ \\
\hline
\end{tabular}

5FU 5-fluorouracil

associated with severe edema. Following surgical resection, the pathology examination confirmed a distant metastasis of ACC of the breast. She was treated with complementary whole brain radiation therapy and no complications were reported. The disease rapidly progressed after 3 months which correlated with the appearance of pancreatic metastases. She was included in a clinical trial.

\section{Discussion}

Adenoid cystic breast carcinoma is a rare form of breast cancer, which is named after its microscopic appearance $[5,6]$. It is a non-aggressive type of breast carcinoma with a very good chance of full recovery and it has a low propensity for metastasis $[7,8]$.

Only two cases of ACC with brain metastases and two other cases with kidney metastases were reported in the literature [9-12]; the characteristics of the patients, their tumors, and their management are summarized in Table 1. To the best of our knowledge, this is the first case of ACC that metastasized to lung, kidney, and brain.

The initial treatment of our patient was in line with published guidelines. Local therapy can consist in a simple or modified radical mastectomy or lumpectomy associated with radiotherapy $[13,14]$. Axillary node dissection is not recommended in view of the very low incidence of axillary lymph node metastasis that does not exceed 2\% [8]. Similarly, there is no indication for adjuvant chemotherapy and several small studies did not suggest a survival benefit on overall survival, when adding adjuvant chemotherapy [15].

Due to the rarity of ACC with metastases, treatment recommendations are sparse. Some physicians are extrapolating the treatment of ACC of the breast from the one of the salivary glands, the most frequent localization of ACC. For patients with metastatic disease, some cytotoxic agents have been used including vinorelbine, 5-fluorouracil (5FU), and doxorubicin $[11,12]$.

Mitoxantrone was evaluated in advanced ACC of the head and neck region with no significant anti-tumor activity in one trial and modest activity in another $(12 \%$ of response rate) $[16,17]$. This drug was not tested in ACC of the breast before. We administered mitoxantrone to our patient for eight cycles and she presented a stable disease in her lung metastases. Mitoxantrone was chosen because of its favorable toxicity profile, including no hair loss.

We did evaluate the genetic alterations of her tumor hoping for actionable genetic aberrations. Unfortunately, our target gene sequencing did not reveal any mutation or copy number aberration that would justify the use of a particular targeted drug. A recently published study described specific genetic alterations in rare breast cancer tumors (micropapillary, metaplastic, pleomorphic lobular) [14]. In another reported case in the literature of ACC metastasizing to the kidney, a PI3K mutation was detected [10]. Progress in these rare tumor types might occur through the conduct of basket trials in the future.

\section{Conclusions}

ACC is a rare neoplasm of the breast. Management of a metastatic situation presents challenges for medical oncologists. The benefit of using chemotherapy and the definition of which agent should be used remain unknown because of the paucity of reported cases in metastatic situations. It is necessary to have other cases before establishing a consensus for this type of tumor.

Abbreviations

5FU: 5-Fluorouracil; ACC: Adenoid cystic carcinoma; TNBC: Triple negative breast cancer

Acknowledgements

Not applicable. 


\section{Funding}

The authors received no specific funding for this study.

\section{Availability of data and materials}

Not applicable.

\section{Authors' contributions}

The authors participated in the management of the patient and the writing of the manuscript. The final version has been reviewed and approved by all authors.

Ethics approval and consent to participate

Not applicable.

\section{Consent for publication}

Written informed consent was obtained from the patient for publication of this case report and any accompanying images. A copy of the written consent is available for review by the Editor-in-Chief of this journal.

\section{Competing interests}

The authors declare that they have no competing interests.

\section{Publisher's Note}

Springer Nature remains neutral with regard to jurisdictional claims in published maps and institutional affiliations.

\section{Author details}

${ }^{1}$ Department of Medical Oncology, University Hospital of Marrakech, Marrakech, Morocco. ${ }^{2}$ Department of Oncology, Faculty of Medicine, Saint Joseph University, Beirut, Lebanon. ${ }^{3}$ Department of Medical Oncology, Jules Bordet Institute, Université Libre de Bruxelles, Brussels, Belgium.

Received: 7 June 2017 Accepted: 18 September 2017

Published online: 29 October 2017

\section{References}

1. Coca-Pelaz A, Rodrigo JP, Bradley PJ. Adenoid cystic carcinoma of the head and neck - An update. Oral Oncol. 2015;51(7):652-61.

2. Kim M, Lee DW, Im J, Suh KJ, Keam B, Moon HG, et al. Adenoid Cystic Carcinoma of the Breast: A Case Series of Six Patients and Literature Review. Cancer Res Treat. 2014;46(1):93-7.

3. Senger JL, Kanthan R. Adenoid Cystic Carcinoma of the Breast A Focused Review. JSM Surg Oncol Res. 2016:1(2):1008.

4. Canyilmaz E, Hanedan Ulsu G, Memis Y. Adenoid cystic carcinoma of the breast: A case report and literature review. Oncol Lett. 2014;7(5):1599-601.

5. Miyai K, Schwartz MR, Divatia MK, Anton RC, Park WR, Ayala AG, Ro J. Adenoid cystic carcinoma of breast: Recent advances. World J Clin Cases. 2014;2(12):732-41.

6. Arpino G, Clark GM, Mohsen S, et al. Adenoid cystic carcinoma of the breast. Molecular markers, treatment and clinical outcome. Cancer. 2002;94:2119-17.

7. Kulkarni N, Pezzi CM, Greif JM, et al. Rare breast cancer: 933 Adenoid cystic carcinomas from the national cancer data base. Ann Surg Oncol. 2013;20(7): 2236-41.

8. Boujelbene N, Khabir A, Boujelbene N, et al. Clinical review - breast adenoid cystic carcinoma. Breast. 2012;21(2):124-7.

9. Herzberg AJ, Bossen EH, Walther PJ, et al. Adenoid cystic carcinoma of the breast metastatic to the kidney. A clinically symptomatic lesion requiring surgical management. Cancer. 1991:68(5):1015-20.

10. Vranic S, Bilalovic N, Lee $L$, et al. PI3K3CA and PTEN mutations in adenoid cystic carcinoma of the breast metastatic to kidney. Hum Pathol. 2007:38(9):1425-31.

11. Koller M, Ram Z, Findler $G$, et al. Brain Metastasis: A rare manifestation of adenoid cystic carcinoma of the breast. Surg Neurol. 1986;26(5):470-2.

12. Silva I, Tome V, Oliveira J. Adenoid cystic carcinoma of the breast with cerebral metastisation: a clinical novelty. BMJ. 2011;2011. doi:10.1136/bcr.08.2011.4692

13. Coates JM, Martinez SR, Bold RJ, et al. Adjuvant radiation therapy is associated with improved survival for adenoid cystic carcinoma of the breast. J Surg Onco. 2010;102(4):342-7.

14. Khanfir K, Kallel A, Villette S, Belkacémi Y, et al. Management of adenoid cystic carcinoma of the breast: a Rare Cancer Network study. Int J Radiat Onco. 2012;82(5):2118-24.
15. Ghabach B, Anderson WF, Curtis RE, et al. Adenoid cystic carcinoma of the breast in the United States (1977 to 2006): a population-based cohort study. Breast Cancer Res. 2010;12(4):R54

16. Mattox DE, Von Hoff DD, Balcerzak SP. Southwest Oncology Group study of mitoxantrone for treatment of patients with advanced adenoid cystic carcinoma of the head and neck. Invest New Drugs. 1990;8(1):105-7.

17. Verweij J, Mulder PH, De Graeff A, et al. Phase II study on mitoxantrone in adenoid cystic carcinoma of the head and neck. EORTC Head and Neck Cancer Cooperative Group. Ann Oncol. 1996;7(8):867-9.

\section{Submit your next manuscript to BioMed Central and we will help you at every step:}

- We accept pre-submission inquiries

- Our selector tool helps you to find the most relevant journal

- We provide round the clock customer support

- Convenient online submission

- Thorough peer review

- Inclusion in PubMed and all major indexing services

- Maximum visibility for your research

Submit your manuscript at www.biomedcentral.com/submit
Biomed Central 